\title{
Phenotypic and functional heterogeneity of macrophages and dendritic cell subsets in the healthy and atherosclerosis-prone aorta
}

\author{
Matthew J. Butcher and Elena V. Galkina* \\ Department of Microbiology and Molecular Cell Biology, Eastern Virginia Medical School, Norfolk, VA, USA
}

\section{Edited by:}

Klaus Ley, La Jolla Institute for Allergy and Immunology, USA

Reviewed by:

Roy Sutliff, Emory University, USA Jeng-Jiann Chiu, National Health

Research Institutes, Taiwan

${ }^{*}$ Correspondence:

Elena V. Galkina, Department of Microbiology and Molecular Cell Biology, Eastern Virginia Medical School, 700 West Olney Road, Norfolk, VA 23507-1696, USA. e-mail: galkinev@evms.edu

\begin{abstract}
Atherosclerosis continues to be the leading cause of cardiovascular disease. Development of atherosclerosis depends on chronic inflammation in the aorta and multiple immune cells are involved in this process. Importantly, resident macrophages and dendritic cells (DCs) are present within the healthy aorta, but the functions of these cells remain poorly characterized. Local inflammation within the aortic wall promotes the recruitment of monocytes and DC precursors to the aorta and micro-environmental factors direct the differentiation of these emigrated cells into multiple subsets of macrophages and DCs. Recent data suggest that several populations of macrophages and DCs can co-exist within the aorta. Although the functions of M1, M2, Mox, and M4 macrophages are well characterized in vitro, there is a limited set of data on the role of these populations in atherogenesis in vivo. Recent studies on the origin and the potential role of aortic DCs provide novel insights into the biology of aortic DC subsets and prospective mechanisms of the immune response in atherosclerosis. This review integrates the results of experiments analyzing heterogeneity of DCs and macrophage subsets in healthy and diseased vessels and briefly discusses the known and potential functions of these cells in atherogenesis.
\end{abstract}

Keywords: atherosclerosis, immune response, monocytes, dendritic cells, macrophages

\section{THE DISCOVERY OF MACROPHAGES AND DENDRITIC CELLS WITHIN THE AORTA}

For almost a century, macrophages have been known to be the cells that are involved in atherosclerosis. Anitschkow (1913) discovered that early and advanced atherosclerotic plaques are developed in direct correlation with the amount of dietary cholesterol. Anitschkow also identified some lesional leukocytes as "large cells with a foamy protoplasma" containing cholesterol derivates in small vacuoles, which he considered to be derived from blood lymphocytes or Langerhans' cells. He named these cells "cholesterolesterphagocytes," based on their probable etiology and assumed function. The idea that monocytes are involved in the induction and persistence of atherosclerosis was extensively studied during the following decades and this hypothesis received additional confirmation from various immunohistochemical studies. Hoff (1972) reported the existence of mononuclear cells that were ultrastructurally identified as monocytes by the presence of cytoplasmic peroxisomes in the intima, in endothelial junctions, and among the endothelium of human aortas obtained at autopsy. In an electron-microscopic survey of the aorta in the adult rat, white blood cells were found to adhere to the intima; which were invariably lymphocytes or monocytes (Joris et al., 1979). Alpha-naphtyl acetate esterase-positive (ANAE) monocytes were also detected within the central and peripheral areas of lesions within rabbit aortas (Hansson et al., 1980). Further characterization of these cells provided evidence suggesting the existence of aortic macrophages $(M \Phi$; Gerrity, 1981; Jonasson et al., 1986) and CD1a ${ }^{+}$dendritic cells (DCs;
Bobryshev and Lord, 1998) within the subendothelial space of the intima.

\section{VASCULAR DENDRITIC CELLS IN HEALTHY AORTAS}

The phenotype and markers of identification vary for $M \Phi s$ and DCs within several tissues and often depend on the degree of maturation and activation (Mosser and Edwards, 2008; Geissmann et al., 2010). With respect to DCs located within the aorta, several studies have reported unique features of human aortic DCs that express $\mathrm{CD} 1 \mathrm{a}^{+} \mathrm{S}-100^{+} \mathrm{lag}^{+} \mathrm{CD} 31^{-} \mathrm{CD} 83^{-} \mathrm{CD} 86^{-}$and resemble Langerhan's cells (Bobryshev, 2010). These vascular-associated DCs were named vascular DCs (Bobryshev and Lord, 1995). Additional seminal studies demonstrated the presence of resident DCs in apparently healthy, non-diseased aortas (Bobryshev and Lord, 1995; Waltner-Romen et al., 1998; Millonig et al., 2001; Ma-Krupa et al., 2004). Interestingly, DCs display distinct anatomical features when located at different layers of the aorta, and probably the adventitia as well. Structurally low-differentiated DCs are predominantly found in close proximity to the endothelium within the normal intima, whereas DCs with a moderately developed tubulovesicular system are localized throughout the thickness of the tunica intima, mostly being concentrated in the subendothelial space (Bobryshev, 2010), suggesting distinct structural and probably functional differences between subsets of DCs located at different areas of the aortic wall.

Recent studies using advanced techniques such as confocal microscopy, monocyte-labeling technique, and flow cytometrybased analysis have further provided fascinating data about the 
accumulation of DCs and $\mathrm{M} \Phi$ within the healthy artery. Flow cytometric analysis of $C 57 B L / 6$ aortas clearly demonstrated the presence of aortic CD11c ${ }^{+} \mathrm{CD} 40^{+}$cells (Galkina et al., 2006). However, as whole aortas were digested with enzymes, this approach permitted the characterization of leukocytes within the aorta, but did not provide data about the anatomical distribution of DCs within the aortic wall. Additional studies utilizing confocal microscopy revealed the presence of bone-marrow-derived $\mathrm{CD}_{11 \mathrm{c}^{+}}$cells within the intima of healthy aortas of $\mathrm{C} 57 \mathrm{BL} / 6$ mice (Jongstra-Bilen et al., 2006).

Why would DCs accumulate within the healthy non-diseased artery? It is well-known that atherosclerosis is a site-specific disease characterized by the preferential development of plaques at the lesser curvature of the aorta, and that flow-dependent activation of the aortic endothelium is partially responsible for the accelerated recruitment of monocytes and DC-precursors to atherosclerosisprone areas. Interestingly, an abundance of $\mathrm{CD}^{2} 8^{+} \mathrm{CD} 11 \mathrm{c}^{+}$cells, but not $\mathrm{CD}^{+} 8^{+}$macrophages were detected within the lesionsusceptible lesser curvature of the healthy aortic intima (JongstraBilen et al., 2006). Thus, the initial localization of intimal CD $11 c^{+}$ cells is determined by the micro-environment at specific anatomical locations. However, the site-specific localization of intimal CD11 $c^{+}$cells occurs independent of circulating cholesterol levels, highlighting the importance of blood flow patterns rather than plasma lipid levels in the direction of DC localization within the aorta. Additional characterization of DCs by Choi et al. (2009) revealed preferential accumulation of these cells within the cardiac valve and aortic sinus of C57BL/6 mice. These aortic DCs expressed low levels of CD40 and were positive for CD1d, CD80, and CD86 antigens, suggesting that they possess an immature DC phenotype (Table 1).

CD11c is not a unique marker for DCs, since some subsets of MФs are CD11c (Geissmann et al., 2010). Until recently, questions concerning the origin and sub-type of intimal CD11c ${ }^{+}$cells that reside within healthy aortas were unresolved. DCs are generated at least by two major pathways that differ in their requirement for the Flt3/Flt3 ligand (Flt3L) axis. Development of DCs from monocyte-independent precursors is Flt-3/Flt3L-dependent (Naik et al., 2006; Onai et al., 2006; Liu et al., 2009), whereas the generation of DCs from monocytes is Flt3/Flt3L-independent (Cheong et al., 2010). To address the dilemma about the developmental source of aortic CD11c ${ }^{+}$cells, Choi et al. (2011) successfully adapted a previously developed flow cytometry-based approach for the analysis of murine aortas (Galkina et al., 2006) and tested the effects of Flt3 on the expansion of aortic CD11c ${ }^{+}$cells. Flt3 treatment resulted in an expansion of $\mathrm{CD} 11 \mathrm{c}^{+}$cells within the intima and adventitia of $C 57 B L / 6$ mice suggesting a DC origin of CD11c ${ }^{+}$MHC-II ${ }^{\text {high }}$ cells.

Additional studies have also demonstrated the existence of two major subsets of DCs as $\mathrm{CD} 11 \mathrm{c}^{+} \mathrm{CD} 11 \mathrm{~b}^{+} \mathrm{F} 4 / 80^{+}$and

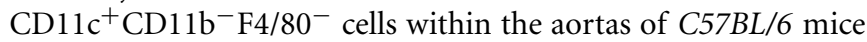

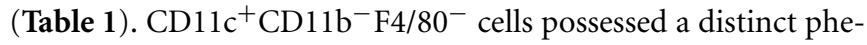
notype characterized by CD103 and CD207 expression, and were negative for CD8, CD205, CX3CR1, and 33D1 (Choi et al., 2011). CD $11 \mathrm{c}^{+} \mathrm{CD} 11 \mathrm{~b}^{+} \mathrm{F} 4 / 80^{+} \mathrm{CD} 103^{-}$DCs expressed the CD14 co-receptor for TLR4 and DC-SIGN antigen (Table 1). Development of these two subsets of DCs was considerably different: $\mathrm{CD} 11 \mathrm{c}^{+} \mathrm{CD} 11 \mathrm{~b}^{+} \mathrm{F} 4 / 80^{+} \mathrm{CD} 103^{-}$DCs were M-CSFdependent, and likely monocyte-derived DCs. In contrast,

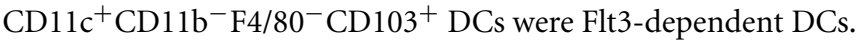

\section{FUNCTIONS WITHIN HEALTHY AORTAS}

The function of vascular DCs within healthy arteries remains unclear; however, recent data suggest that widespread distribution of HLA-DR-expressing cells within the healthy aortic intima may play a role in the maintenance of vascular homeostasis (Bobryshev et al., 2011). Similarly, CD11 ${ }^{+}$DCs may play an active role during the initial stages of atherosclerosis. Jongstra-Bilen et al. (2006) demonstrated that aortic resident $\mathrm{CD}_{11} \mathrm{c}^{+}$DCs actively uptake neutral lipids within high cholesterol diet-fed $\mathrm{Ldlr}^{-/}$mice. Furthermore, as $\mathrm{CD} 11 \mathrm{c}^{+}$DCs are preferentially located within the lesser curvature of the healthy aortas, the initial accumulation of lipids is directed and regulated by CD $11 c^{+}$intimal DCs within the atherosclerosis-prone lesser curvature of the healthy aorta. Interestingly, only a specific subset of $\mathrm{CD} 11 \mathrm{c}^{+} \mathrm{CD} 11 \mathrm{~b}^{-} 33 \mathrm{D} 1^{-} \mathrm{DCs}$ accumulates lipids suggesting that there is a functional complexity between DC subsets in the aorta, which is already reflected at the levels of lipid uptake within relatively non-diseased vessels.

An important question concerning DC functions in atherosclerosis is whether these professional antigen-presenting cells are capable of presenting antigens within the aortic wall. It has been shown that adoptively transferred bone marrow-derived DCs, activated with OVA peptide, induced profound proliferation of TCR-specific lymphocytes that were detected in the spleen and aortas of OT-I recipient mice (Galkina et al., 2006). These results provided initial evidence that $\mathrm{T}$ cells residing within the aorta can be activated by DCs, suggesting that this process may be important in the initiation and/or progression of atherosclerosis. However, this study did not directly address whether aortic DCs are capable of presenting antigens to T cells. In a subsequent study, Choi et al. (2009) convincingly showed that isolated aortic CD11c ${ }^{+}$DCs are able to present OVA peptide to OT-I and OT-II T cells in vitro and in vivo. Importantly, these results correlate with experiments conducted using a model of engineered bioartificial human arteries that mimic the size and structural dimensions of human arteries. Human $\mathrm{CD}_{11} \mathrm{c}^{+}$DCs seeded within bioartificial arteries migrated to the intima, where they triggered TLR-4-dependent T-cell activation, and initiated an adaptive immune response (Han et al., 2008), suggesting that antigen presentation by human DCs can occur in vivo.

\section{ALTERATION OF DENDRITIC CELL POPULATIONS DURING ATHEROGENESIS}

The number of $\mathrm{CD}_{11 \mathrm{c}^{+}}$cells increases with the progression of atherosclerosis in Apoe $e^{-/-}$mice (Galkina and Ley, 2009; Manthey and Zernecke, 2011). DCs are detected in close proximity to $\mathrm{T}$ cells in the zones of neovascularization within atherosclerotic plaques, and near the vasa vasorum in the adventitia. In the shoulder regions of unstable human plaques, $\mathrm{CD} 83^{+} \mathrm{DCs}$ are in close proximity to $\mathrm{CD}_{40 \mathrm{~L}^{+}} \mathrm{T}$ cells (Erbel et al., 2007). There is an increasing number of studies that have focused on the mechanisms underlying the accumulation of $\mathrm{M} \Phi$ s within atherosclerotic aortas (Swirski et al., 2009; Ley et al., 2011); however, there is 
Table 1 | Location and DC phenotype in healthy and atherosclerotic aortas.

\begin{tabular}{|c|c|c|c|c|}
\hline Dendritic cell phenotype & Study population & Locations & $\begin{array}{l}\text { Stages of } \\
\text { atherosclerosis } \\
\text { (demonstrated) }\end{array}$ & Reference \\
\hline 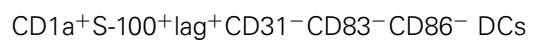 & Humans & Aortic intima & & Bobryshev and Lord (1995) \\
\hline IFN $\alpha^{+}$plasmacytoid DCs & Humans & $\begin{array}{l}\text { Carotid and coronary } \\
\text { arteries }\end{array}$ & Type IV-V and VI & $\begin{array}{l}\text { Erbel et al. (2007), Niessner } \\
\text { et al. (2006) }\end{array}$ \\
\hline $\mathrm{CD}_{11 \mathrm{C}^{+} \mathrm{CD} 40^{+} \mathrm{DCs}}$ & C57BL/6 mice & Aorta & Type 0-I & Galkina et al. (2006) \\
\hline $\mathrm{CD}_{11 \mathrm{c}^{+} \mathrm{CD}^{+} 8^{+} \mathrm{DCs}}$ & C57BL/6 mice & $\begin{array}{l}\text { Aortic intima (lesser } \\
\text { curvature) }\end{array}$ & Type 0-I & Jongstra-Bilen et al. (2006) \\
\hline $\begin{array}{l}\mathrm{CD}_{11 c^{+}} \mathrm{CD} 40^{\text {low }} \mathrm{CD} 1 \mathrm{~d}^{+} \mathrm{CD} 80^{+} \mathrm{CD}^{+} 6^{+} \\
\text {(immature DCs) }\end{array}$ & C57BL/6 mice & $\begin{array}{l}\text { Aorta, aortic sinus } \\
\text { and cardiac valve }\end{array}$ & Type 0-I & Choi et al. (2009) \\
\hline $\begin{array}{l}\text { CD11 }{ }^{+} \text {MHC- } \\
\mathrm{II}^{+} \mathrm{CD} 11 \mathrm{~b}-\mathrm{F} 4 / 80^{-} \mathrm{CD} 207^{+} \mathrm{CD}_{103^{+}} \mathrm{DCs} \\
\text { (Flt-3-dependent, Mn-independent precursors) }\end{array}$ & C57BL/6 mice & Aorta & Type 0-I & Choi et al. (2011) \\
\hline $\begin{array}{l}\text { CD11 } \mathrm{C}^{+} \mathrm{MHC}-\mathrm{II}^{+} \mathrm{CD} 11 \mathrm{~b}^{+} \mathrm{F} 4 / 80^{+} \\
\mathrm{CD}^{+} 4^{+} \mathrm{CD} 103^{-} \mathrm{DC}-\mathrm{SIGN}{ }^{+} \mathrm{DCs} \\
\text { (M-CSF-dependent, Mn-dependent) }\end{array}$ & C57BL/6 mice & Aorta & Type 0-I & Choi et al. (2011) \\
\hline 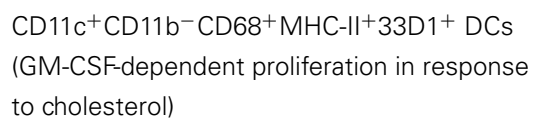 & $\begin{array}{l}\text { Ldl } r^{\prime-} \text { mice }(40 \% \\
\text { fat, } 1.25 \% \text { cholesterol, } \\
1-3 \text { weeks })\end{array}$ & Aortic intima & Type 0-I & Zhu et al. (2009) \\
\hline 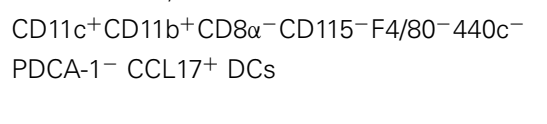 & $\begin{array}{l}\text { Apoe }{ }^{-/-} \text {mice }(21 \% \\
\text { fat, } 0.15 \% \text { cholesterol, } \\
8-12 \text { weeks })\end{array}$ & Aorta and aortic root & Type I-IV & Weber et al. (2011) \\
\hline 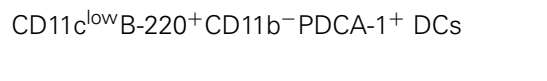 & $\begin{array}{l}\text { Ldl/ }{ }^{\prime-} \text { mice }(0.25 \% \\
\text { cholesterol, } 8 \text { weeks) }\end{array}$ & Aorta & Type I-IV & Daissormont et al. (2011) \\
\hline
\end{tabular}

still limited information about the potential mechanisms of aortic DC accumulation in atherogenesis. Increased DC numbers may be due to increased migration from peripheral circulation, reduced emigration out of the vessel wall or increased local proliferation. A recent study clearly demonstrated that at least for a specific subset of intimal $\mathrm{CD} 11 \mathrm{c}^{+} \mathrm{CD} 11 \mathrm{~b}^{-} \mathrm{CD} 68^{+} \mathrm{MHC}^{-\mathrm{II}^{+}} 33 \mathrm{D} 1^{+}$ DCs, increased granulocyte/macrophage colony-stimulating factor (GM-CSF)-dependent proliferation might be a reason for elevated levels of intimal DCs in the aorta of $\mathrm{Ldlr}^{-/}$mice after a short-term high cholesterol diet (Zhu et al., 2009). Interestingly, aortic $\mathrm{CD} 11 \mathrm{c}^{+} \mathrm{CD} 11 \mathrm{~b}^{-} \mathrm{DCs}$ proliferate independently from Ly6 $\mathrm{C}^{\text {high }}$ monocytes, as $\mathrm{BrDU}^{+}$-proliferating DCs are detected even after PTX-induced blockade of monocyte recruitment to the aorta (Zhu et al., 2009).

Additional characterization of aortas isolated from $\mathrm{Ldlr}^{-/}$ mice fed a high-fat cholesterol diet for 16 weeks further shed light on the dynamics of DC subset accumulation within the aorta (Choi et al., 2009). Unexpectedly, both subsets of aortic $\mathrm{CD} 11 \mathrm{c}^{+} \mathrm{MHC}-\mathrm{II}^{+} \mathrm{CD} 11 \mathrm{~b}^{+} \mathrm{F} 4 / 80^{+}$DCs and $\mathrm{CD} 11 \mathrm{c}^{+} \mathrm{MHC}-$ $\mathrm{II}^{+} \mathrm{CD} 11 \mathrm{~b}^{-} \mathrm{F} 4 / 80^{-} \mathrm{CD} 103^{+}$DCs were elevated in atherosclerotic aortas of $\mathrm{Ldlr}^{-/-}$mice (Choi et al., 2009). To further address questions about the origin of intimal DC subsets, Choi et al. (2011) generated $\mathrm{Flt3}^{-/} \mathrm{Ldlr}^{-/}$mice and investigated the distribution of DC subsets within the aortic intima of atherosclerotic aortas. The numbers of $\mathrm{CD} 11 \mathrm{c}^{+} \mathrm{CD} 11 \mathrm{~b}^{-} \mathrm{CD} 103^{+} \mathrm{DCs}$, but not

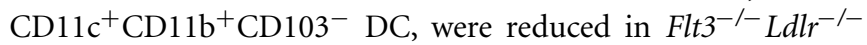
mice, suggesting that aortic $\mathrm{CD} 11 \mathrm{c}^{+} \mathrm{CD} 11 \mathrm{~b}^{-} \mathrm{CD} 103^{+}$DCs are generated from a Flt3-dependent DC precursor.

\section{POSSIBLE IMPLICATION OF DENDRITIC CELLS IN ATHEROSCLEROSIS}

To date, there is strong evidence that DC subsets actively participate in the positive and negative regulation of the immune response. GM-CSF-dependent $\mathrm{CD} 8 \alpha^{+} 33 \mathrm{D} 1^{-}{ }^{-} \mathrm{DEC}_{20} 5^{+} \mathrm{r}$ cells induces high levels of Th1 cytokines IFN $\gamma$ and IL-2, whereas $\mathrm{CD} 8 \alpha^{-} 33 \mathrm{D} 1^{+} \mathrm{DEC}^{205^{-}}$cells, which are FLT-3-dependent, induce also large amounts of IL-4 and IL-10 (Pulendran et al., 1999). Plasmacytoid DCs (pDCs) sense viral nucleic acids and produce a large amount of type I interferons. But also can play an important role in the induction of tolerance. Lung pDCs induce oral tolerance (Lewkowich et al., 2008), where as gut-associated $\mathrm{CD}_{103}{ }^{+}$DCs play roles in the regulation of the balance between Tregs and Th1 cells (Annacker et al., 2005).

The identification of DC functions in atherosclerosis has presented a considerable challenge, as aortic DCs display molecular markers and features of several cell types and can be probably derived from multiple progenitors (Geissmann et al., 2010; Niessner and Weyand, 2010). Nevertheless, recent studies have firmly established the presence of DCs within the healthy and atherosclerosis-prone aorta, and have started to address questions about the functions of DC subsets in lymphoid organs and the aorta in atherosclerosis (Randolph, 2009).

Several lines of evidence suggest that hypercholesterolemia affects the ability of DCs to migrate from peripheral tissues to draining lymph nodes during atherogenesis (Angeli et al., 2004). Prolonged retention of MФs and DCs might also support their pro-inflammatory status and the progression of lesions within 
atherosclerotic aortas (Llodra et al., 2004). However, evidence also suggests that DCs maintain their capacity to prime naïve $\mathrm{T}$ cells under the conditions of hypercholesterolemia (Packard et al., 2008). DCs isolated from $L_{d l r^{-/}}$or $A p o e^{-/-}$mice efficiently induce T-cell proliferation, IFN $\gamma$, and TNF $\alpha$ production after ex vivo co-culture with naïve $\mathrm{CD} 4^{+} \mathrm{T}$ cells (Packard et al., 2008). It is worth noting that hyperlipidemia also increases the levels of blood circulating $\mathrm{CD}_{11 \mathrm{c}^{+}}$monocytes and upregulates their expression of CD11b and CD29. CD11c deficiency reduces monocyte/macrophage accumulation in atherosclerotic lesions and attenuates atherogenesis in $C d 11 c^{-/-} A p o e^{-/-}$mice fed a highfat diet. Interestingly, deficiency of CD11c decreases the firm arrest of mouse monocytes to vascular cell adhesion molecule-1 (VCAM1) and E-selectin in a shear flow assay (Wu et al., 2009). Thus, elevated cholesterol levels not only provide possible antigens for DCs, but also regulate the accumulation of $\mathrm{CD}_{11 c^{+}}$monocytes and potentially DC numbers in the aortic wall.

Dendritic cells are specialized in capturing, processing, and presenting antigen-derived peptides on major histocompatibility complex (MHC) molecules in vivo, thereby, allowing DCs to shape T-cell responses to modulate immunity or tolerance (Steinman, 2007). Numerous bodies of evidence have demonstrated that oxLDL plays a pivotal role in the formation of foam cells, induction of vascular dysfunction, and the support of leukocyte migration to the atherosclerosis-prone aorta (Matsuura et al., 2006). Importantly, modified lipids likely affect the maturation and phenotype of DCs. OxLDL during the late stage of monocyte differentiation gives rise to phenotypically mature DCs that secrete IL-12 but not IL-10, and support both syngeneic and allogeneic Tcell stimulation (Perrin-Cocon et al., 2001). In contrast, oxidized phospholipids (ox-PLs) alter DC activation and prevent their maturation through the blockade of TLR-3- and TLR-4-dependent induction of CD40, CD80, CD83, and CD86 (Bluml et al., 2005). It remains to be determined if only specific sets of lipids affect DC functions and whether distinct subsets of DCs respond selectively to modified lipid loading.

oxLDL serves as a potential source of antigens in atherosclerosis and DCs might present antigens derived from oxLDL to induce a specific T-cell response. Additionally, not only oxLDL, but also other antigens, including beta-2 glycoprotein I ( $\beta 2 \mathrm{GPI})$ and heat shock proteins HSP-60 and HSP-65 activate T cells. Recently, our understanding of the oxidation hypothesis of atherosclerosis was altered and some attention has shifted toward native LDL, as potential antigens for atherosclerosis. In the elegant and extensive work by Hermansson et al. (2010), the authors focused on identifying the potential mechanism of oxLDL recognition by $\mathrm{T}$ cells via generation of T-cell hybridomas from human apolipoprotein B100 transgenic mice that were immunized with human oxLDL. Unexpectedly, T-cell hybridomas responded to native and purified LDL apolipoprotein ApoB100, but not to oxLDL, suggesting the existence of an immune response against native LDL. Subsequent studies have demonstrated that immunization with lipid-loaded DCs resulted in various effects on the progression of atherosclerosis and local modulation of inflammation within the aortic wall (de Jager and Kuiper, 2011). However, despite important insights into the biology of DCs, there are a limited number of studies that have tested the effects of oxLDL and native LDL on DC functions, and the consequences of modified lipid uptake for T-cell differentiation and activation.

To investigate the role of CD11 ${ }^{+}$DC in atherogenesis, Gautier et al. (2009) generated a mouse model with the over-expression of the anti-apoptotic gene hBcl-2 under the control of the CD11c promoter. It should be noted that $\mathrm{Bcl} 2$ expression was not detected on $\mathrm{pDC}$ and $\mathrm{CD} 11 \mathrm{~b}^{+} \mathrm{F} 4 / 80^{+}$monocytes indicating that in this model, the major effects of $\mathrm{Bcl} 2$ over-expression were directed toward CD11 $\mathrm{c}^{\text {high }} \mathrm{MHC}-\mathrm{II}^{\text {high }}$ cells. The CD11 $\mathrm{c}^{\text {high }} \mathrm{MHC}-\mathrm{II}^{\text {high }}$ DC population was increased in DC-hBcl 2 mice, and was associated with enhanced T-cell activation, elevated levels of Th1, Th17related cytokines, and increased production of Th1-driven IgG2c antibodies. Unexpectedly, increased levels of $\mathrm{CD}_{11 \mathrm{c}^{+}}$cells also resulted in reduced plasma cholesterol. In line with these results, the depletion of DCs in hyperlipidemic CD11c-diphtheria toxin receptor (DTR) Apoe $e^{-/-}$transgenic mice resulted in enhanced cholesterolemia. These data suggest a strong relationship between CD11c-expressing cells and cholesterol homeostasis. To date, the mechanisms that regulate $\mathrm{CD}_{11 \mathrm{c}^{+}}$cell-dependent cholesterol metabolism are unknown.

A new approach was recently taken to study the potential

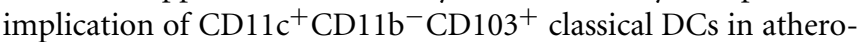
sclerosis using Flt-3-/- $\mathrm{Ldlr}^{-/-}$mice (Choi et al., 2011). Deficiency of Flt- 3 and therefore, depletion of CD11 ${ }^{+} \mathrm{CD} 11 \mathrm{~b}^{-} \mathrm{CD}_{103^{+}} \mathrm{DCs}$ resulted in increased plaque burden within the aortic sinus and the aortic arch. This accelerated atherogenesis was accompanied by the reduction of Treg in the aorta and increased levels of aortic IFN $\gamma$ and $\mathrm{TNF} \alpha$ without significant alteration in the lipid levels (Choi et al., 2011). Thus, aortic CD11c ${ }^{+}$CD103 ${ }^{+}$DCs likely function as tolerogenic DCs during atherosclerosis. Although traditionally viewed as the main inducers of immunity, DCs are also important players in the induction and maintenance of peripheral self-tolerance (Steinman et al., 2003). As Treg cells are the key component of a suppressor anti-atherogenic arm of the immune response, aortic $\mathrm{CD} 11 \mathrm{c}^{+} \mathrm{CD}_{103^{+}} \mathrm{DCs}$ may play an important role in their generation. Recently another subset of CCL17-expressing DCs was identified as an important player in atherosclerosis (Weber et al., 2011). DC-derived CCL17 limited the expansion of Tregs and increased the plaque burden. In contrast, blocking antibodies against CCL17 maintained Treg differentiation and attenuated atherosclerosis. These new results suggest the existence of a CCL17-specific DC subset that has the capacity to alter Treg homeostasis in atherogenesis. To date, the mechanisms that control the number and suppressor functions of Tregs in atherosclerosis are not well understood, but the recently discovered functions of $\mathrm{CD} 11 \mathrm{c}^{+} \mathrm{CD} 11 \mathrm{~b}^{-} \mathrm{CD} 103^{+}$DCs and $\mathrm{CCL}^{+} 7^{+} \mathrm{DCs}$ offer some evidence to suggest that DC-mediated regulation of Treg occurs in atherosclerosis.

\section{PLASMACYTOID DCs}

Recent studies have further characterized several subsets of DCs and have resulted in a deeper understanding of the heterogeneity and origin of vascular DCs. pDCs are a distinct subset of DCs specialized in direct virus TLR7, TLR8, and TLR9-dependent recognition that results in rapid induction of high levels of type I interferon (interferon $\alpha / \beta$, IFN) and other cytokines. pDCs are closely related to classical antigen-presenting DC, since these cells 
have some common developmental origin and genetic similarity (Reizis et al., 2011). The characterization of pDC lineage has presented a considerable challenge, as pDCs display molecular markers and features of several cell types, and can be derived from multiple progenitors. Typically, pDCs show only low expression of CD11c, while this marker is abundantly expressed by myeloid DCs (mDCs). Ironically, pDCs also express some lymphocyte antigens including CD4, Rag-1, CD45RA/B220, and pIII transcript of the MHC class II transactivator (CIITA). One of the remaining enigmas of $\mathrm{pDC}$ biology concerns their ability to present antigen (Villadangos and Young, 2008). pDCs are found to be weak antigen-presenting cells compared with classical DCs. Instead, pDCs are considered immunomodulating cells that can direct the immune response by tipping the balance of $\mathrm{T}$ helper responses via their secretion of type I interferons.

There are several lines of evidence suggesting that pDCs might have a role in atherosclerosis. IFN $\alpha^{+}$pDCs are detected within atherosclerosis-prone vessels (Bobryshev and Lord, 1995; Niessner et al., 2006; Daissormont et al., 2011), with preferential expression within the shoulder region of atherosclerotic plaques. One of the important pieces of data to suggest a pro-inflammatory role of pDCs came from a study demonstrating that type I IFNs, released by $\mathrm{pDCs}$, can induce the expression of tumor necrosis factor-related apoptosis-inducing ligand (TRAIL) on CD4 ${ }^{+} \mathrm{T}$ cells (Niessner et al., 2006). Furthermore, adoptive transfer of human plaque-isolated $\mathrm{CD}^{+}{ }^{+} \mathrm{T}$ cells into immunodeficient mice that are engrafted with human atherosclerotic plaque results in apoptosis of VSMCs in a TRAIL-dependent manner (Sato et al., 2006). Altogether, these series of experiments suggest an important link between aortic pDCs, the induction of TRAIL on T cells, and possible TRAIL-dependent T cell-induced apoptosis of VSMCs.

In addition to the activities of pDCs as an immunogenic cell sentinel, pDCs can also act as tolerogeneic cells when expressing inducible tolerogenic enzyme indoleamine 2,3-dioxygenase (IDO), the inducible costimulator ligand (ICOS-L), and/or the programmed death 1 ligand (PD-L1), which mediates Treg development (Colonna et al., 2004; Matta et al., 2010). A recent study by Daissormont et al. (2011) further addressed the potential role of pDCs and reported an anti-inflammatory activity of pDCs during atherogenesis. Surprisingly, pDC depletion by $120 \mathrm{G} 8 \mathrm{mAb}$, which recognizes PDCA-1 (marrow stromal cell antigen 2, BST2), a marker exclusively expressed on mouse pDC, increased plaque burden in $\mathrm{Ldlr}^{-/}$recipient mice (Daissormont et al., 2011). This acceleration of atherosclerosis was accompanied by increased T-cell proliferation, elevated IFN $\gamma$ production and reduced expression of IDO in pDCs isolated from lymphoid tissue. These results highlight the tolerogenic functions of pDCs and suggest that this subset of DCs may play an important role in maintaining the balance between Th1 and Treg cells during atherogenesis in aortas and secondary lymphoid organs. Eicosapentaenoic acid (EPA) has beneficial effects on cardiovascular diseases, although the precise mechanism is unknown. Interestingly, the treatment with EPA attenuates atherosclerosis and increases the number of

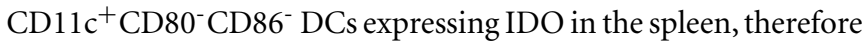
inducing tolerogenic phenotype of DCs (Nakajima et al., 2011).

Plasmacytoid DCs are not tolerogenic under basal, nonstimulated conditions and have shown no IDO expression. Specific engagement of B7-1 receptors by CD152-Ig (CTLA-4-Ig) or CD200R1 by CD200-Ig lead to initiating of IDO-dependent tolerance (Reizis et al., 2011). Thus, the functional relationships between $\mathrm{pDCs}$ roles as the inducers of the immune response versus tolerance are dependent on multiple ligands and likely cytokines that contribute to the expression of a tolerogenic phenotype by pDCs. Although the somewhat current data about the role of pDCs are debatable, they clearly emphasize the complexity of pDC functions in atherosclerosis. It will be important to understand how increased levels of potential antigens from the necrotic core and the alterations in the T-cell response affect DC functions during atherogenesis. Recent studies that have focused on the role of DCs in atherosclerosis also raise the tantalizing question of whether the antigen-presenting functions of DCs will be a key component in the regulation of the immune response in atherosclerosis.

\section{THE ROLE OF MACROPHAGES IN ATHEROSCLEROSIS}

Macrophages (MФ) were the first inflammatory cells to be associated with atherosclerosis, where they represent the major cell type in atherogenesis and play important roles in the progression of the lesions. The essential role of $M \Phi s$ in the initiation and progression of atherosclerosis was initially demonstrated using $\mathrm{M}$ CSF-deficient osteopetrotic (op) Apoe $e^{-/-}$mice, which resulted in a dramatic $86 \%$ reduction in plaque volume (Smith et al., 1995). More recently, a model of CD11b promoter-diptheria toxin transgenic Apoe $e^{-/-}$chimeric mice with CD11b-DTR bone marrow was used to deplete $\mathrm{CD}_{11 \mathrm{~b}^{+}}$cells and test the role of $\mathrm{CD} 11 \mathrm{~b}^{+}$cells in atherogenesis (Stoneman et al., 2007). CD11b ${ }^{+}$cell depletion significantly affected plaque development and altered plaque composition in the early stages of atherogenesis. However, despite a $50 \%$ reduction of monocytes in mice with advanced plaques, the depletion of $\mathrm{CD} 1 \mathrm{~b}^{+}$cells had no effect on the extent of plaques or the composition of advanced lesions. Because monocytes, $\mathrm{M} \Phi$, neutrophils, and a subset of DCs express CD11b, and have been implicated in the pathology of atherosclerosis, the specific contributions of $M \Phi$ and $M \Phi$ subsets to the observed phenotypes were uncertain. Using an analogous method, Paulson et al. (2010), recently used CD11c-DTR $\mathrm{Ldlr}^{-/}$chimeric mice to investigate the role of CD11c ${ }^{+}$DCs in atherogenesis (Gautier et al., 2009). CD11c-DTR $\mathrm{Ldlr}^{-/}$chimeric mice fed a cholesterol-rich diet for 5-10 days displayed a 55\% reduction in intimal lipid area in comparison to un-depleted control mice, suggesting a pro-atherogenic role for $\mathrm{CD} 11 \mathrm{c}^{+}$DCs. However, as foam cells can similarly express CD11c, it is unclear whether the observed effects are due to the removal of foam cells or the removal of DCs from the forming atherosclerotic lesions.

\section{MACROPHAGE SUBSETS}

In the initial stages of atherogenesis, blood monocytes adhere to and transmigrate through the endothelial cell layer to differentiate into specialized mononuclear phagocytes. The process of deriving polarized aortic M $\Phi$ and/or DCs from monocytes involves a variety of factors including components of the extracellular matrix, pro-inflammatory cytokines/chemokines, antiinflammatory cytokines/chemokines, oxidized or modified LDL, and CD40/CD40L (Ley et al., 2011; Moore and Tabas, 2011). Recently, the process of $\mathrm{M} \Phi$ polarization during atherogenesis 
has been a subject of interest as $M \Phi$ subsets have been demonstrated to display some degree of plasticity and heterogeneity within atherosclerotic lesions (Ley et al., 2011; Moore and Tabas, 2011; Wolfs et al., 2011). Initially, a model of two modes of $M \Phi$ activation was proposed to differentiate between inflammatory

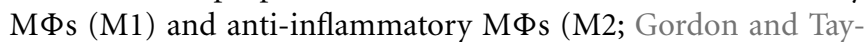
lor, 2005). Pro-inflammatory M1 MФs were originally described from studies conducted in the 1960s by Mackaness and colleagues (Blanden et al., 1969) who demonstrated that murine MФs displayed enhanced anti-microbial activity, in a stimulus dependent manner, in response to Mycobacterium bovis bacillus CalmetteGuerin (BCG) or Listeria monocytogenes infections (Blanden et al., 1969). In contrast, Stein et al. (1992) demonstrated in 1992 that $\mathrm{M} \Phi$ s could be polarized to an "alternative" state (M2) in the presence of IL-4 characterized by expression of the macrophage mannose receptor (CD206). More recently, with the addition of the newer M2 subsets (M2a-c), Mox, and M4 subsets the paradigm of $M \Phi$ activation has been further extended (Ley et al., 2011; Wolfs et al., 2011).

\section{M1 MACROPHAGES}

Following the discovery that M1 and M2 MФ subsets are generated in different inflammatory conditions, the attention of the field was directed toward investigating the generation, phenotype, and possible functions of aortic MФs during atherogenesis. In order to better understand the properties of $M \Phi$ subsets and identify new markers for the recognition of M2 MФs, several approaches for the generation of $M \Phi$ subsets were developed. To date, both human and murine monocytes can be polarized into various $\mathrm{M} \Phi$ subsets in vitro depending on the culture conditions used. Monocyte/macrophage colony-stimulating factor (M-CSF) is a key cytokine for the generation of un-polarized MФs from monocytes in vitro (Stanley et al., 1978). Un-polarized MФs can then be driven toward polarized $\mathrm{M} \Phi$ subsets based on environmental cues. M1 MФs were originally derived and characterized through the combined treatment of un-polarized MФs with IFN $\gamma$ and TNF $\alpha$. This treatment results in the generation of M1 M $\Phi$ s that strongly produce pro-inflammatory cytokines, including IL-1 $\beta$, IL-6, IL8 , IL-12, and TNF $\alpha$, and possess enhanced microbicidal activity (reviewed in Mosser and Edwards, 2008; Ley et al., 2011; Wolfs et al., 2011). Similarly, the use of MyD88-dependent TLR agonists and IFN- $\gamma$ are effective in producing M1 M $\Phi$ s in vitro (Mosser and Edwards, 2008). M1 MФs have been described to exert definitive pro-inflammatory roles, thereby worsening the progression of autoimmune disorders like rheumatoid arthritis, Crohn's disease, multiple sclerosis, or protecting the host from infectious microorganisms (Murray and Wynn, 2011).

While information on the polarization of $M \Phi$ s in vitro is useful as a starting point, the situation in vivo is quite complex. Following transmigration, monocytes can differentiate into $\mathrm{M} \Phi$ via intimal M-CSF (Smith et al., 1995). During this process, unpolarized $M \Phi s$ upregulate the expression of pattern recognition receptors, including toll-like receptors, c-type lectin receptors, scavenger receptors, retinoic acid-inducible gene 1-like helicase receptors, and NOD-like receptors, in order to search the microenvironment for pathogens, foreign substances, apoptotic cells, and oxLDL (Murray and Wynn, 2011). In response to Th1, $\gamma \delta \mathrm{T}$ cell, NK, and NKT cell-derived IFN $\gamma$ and pro-inflammatory TNF $\alpha$, $\mathrm{M} \Phi$ s can polarize toward a classic M1 phenotype that is characterized by high expression of macrophage receptor with collagenous structure (Marco), suppressor of cytokine signaling 3 (Socs3), inducible nitric oxide synthase (Nos2), TNF- $\alpha$, IL-1 $\beta$, IL-6, IL12, IL-23, cyclooxygenase 2 (Cox2), indoleamine 2,3-dioxygenase 1 (Ido1), and the production of reactive oxygen and nitrogen species (Murray and Wynn, 2011). In the context of atherosclerosis, several lines of evidence exist to suggest that M1 MФs are located within both human and murine atherosclerotic plaques. Bouhlel et al. (2007) demonstrated the presence of CCL2 ${ }^{+}$CD206 ${ }^{\text {neg }} M 1$ MФs in human endartectomy specimens. In murine aortas, M1 $\mathrm{M} \Phi$ s are found in high-fat diet-fed $\mathrm{Ldlr}^{-/}$aortas by immunofluorescence and flow cytometry (Kadl et al., 2010). Interestingly, Khallou-Laschet et al. (2010) demonstrated initial accumulation of $\mathrm{M} 2 \mathrm{M} \Phi$ s and further increased in $\mathrm{M} 1 \mathrm{M} \Phi$ s within the advanced lesions of $A p o e^{-/-}$mice.

While the specific effects of M1-derived pro-inflammatory factors have not been assessed in atherosclerosis, in vitro data and global cytokine knockout studies have provided some insight concerning the functions that M1 MФs may exert in situ. The effects of TNF $\alpha$ and other pro-inflammatory cytokines on the vascular endothelium and smooth muscle cell layer are well established. As M1 M $\Phi$ s secrete elevated levels of $T N F \alpha$, IL-1 $\beta$, and IL-6, these M1-derived cytokines may play a role in further activating endothelial and smooth muscle cells, resulting in the upregulation of endothelial and smooth muscle cell chemokines; and may play a role in endothelial dysfunction via down-regulation of endothelial eNOS expression and ROS/RNS driven oxidative stress (Figure 1; Table 2). Similarly, M1 MФs may play a role in driving the generation of the pro-inflammatory Th1 cell and controversial Th17 cell subsets, thereby promoting further inflammation (Butcher and Galkina, 2011; Murray and Wynn, 2011). In addition, as bone marrow macrophage-derived M1 MФs strongly phagocytose oxLDL, secrete matrix metalloproteases (MMP1, MMP3, and MMP9), and are poor efferocytes in vitro, M1 MФs may play a role in promoting the formation of a large necrotic core, plaque destabilization, and thrombus formation (Ley et al., 2011; Moore and Tabas, 2011; Murray and Wynn, 2011; Wolfs et al., 2011).

\section{M2 MACROPHAGES}

M2 MФs were originally derived from monocyte-derived M $\Phi$ s with M-CSF and IL-4 (Stein et al., 1992) and defined based on the expression of the macrophage mannose receptor (CD206); however, more recent studies have found that $M \Phi$ phenotypes reminiscent of M2 MФs can also be produced in vitro. In vitro, alternative MФs (M2a) can be polarized using M-CSF and the Th2-related cytokines IL-4 or IL-13. Similarly, the M2b phenotype can be obtained in the presence of immune complexes and IL- $1 \beta$ or LPS, while M $2 \mathrm{c} M \Phi$ s can be derived using IL- 10 , TGF $\beta$, or glucocorticoids (Mosser and Edwards, 2008; Ley et al., 2011; Wolfs et al., 2011). What would be a source of M2 cytokines within the atherosclerotic aorta? Mast cells and Th2 cells are found within atherosclerotic aortas and can serve as a potential source of IL-1 $\beta$, IL-4, IL-13, and IL-10 cytokines, which may in turn polarize MФs toward alternative activation phenotypes. 


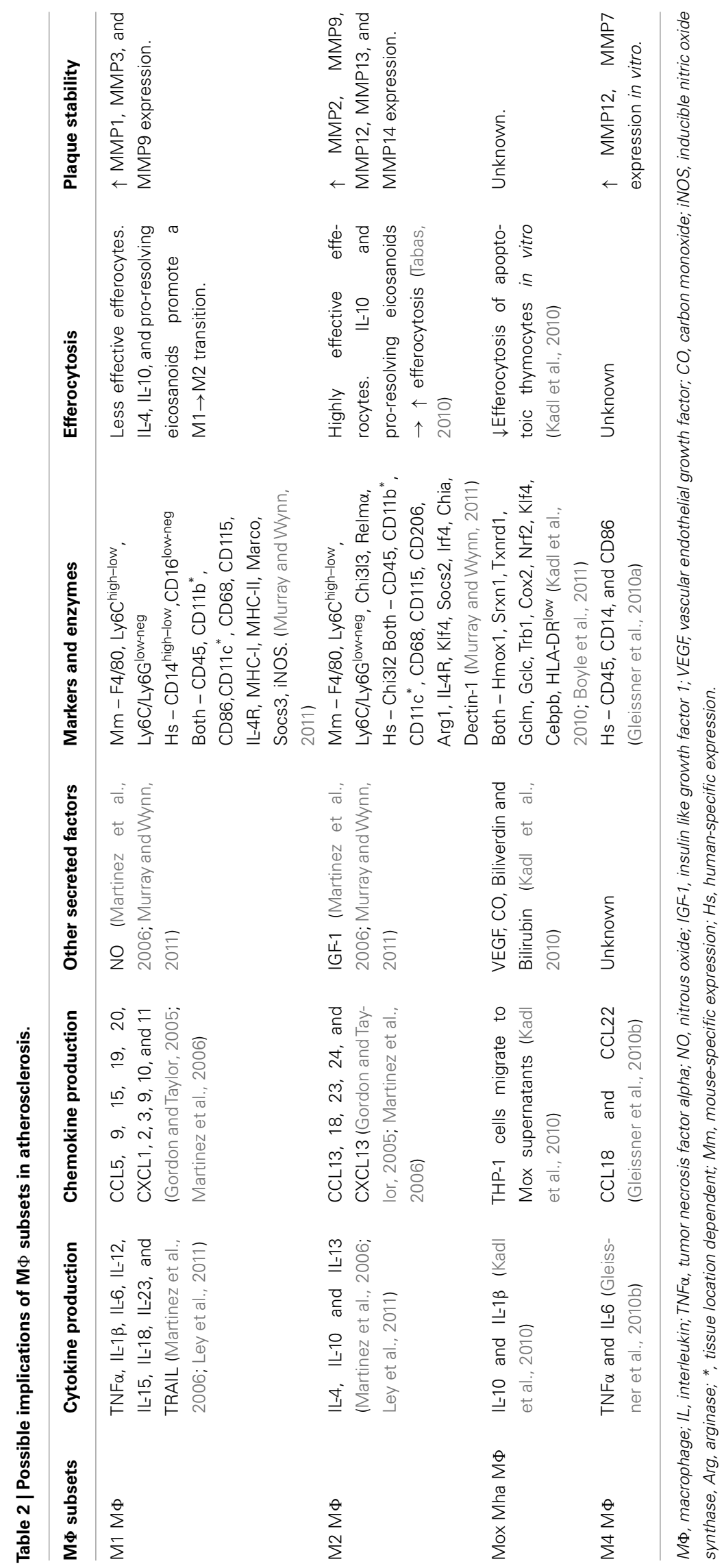




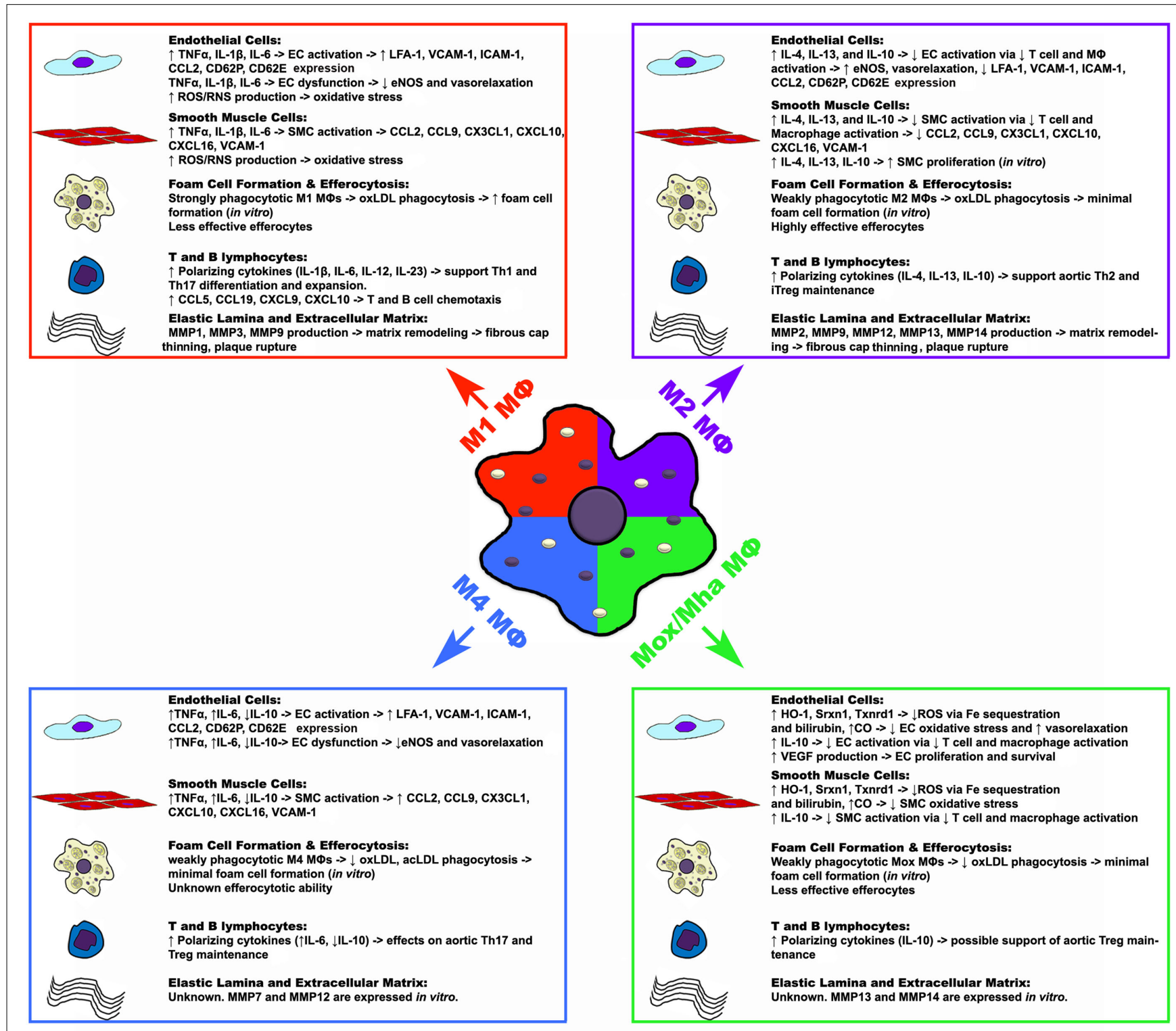

FIGURE 1 | Potential functions of macrophage polarization states in atherosclerosis. Upon activation, macrophages can assume different polarization states in response to environmental cues, which may have various effects on the components of atherosclerotic plaques. While M1, M2, and Mox/Mha subsets have been shown to exist in atherosclerotic plaques, the presence of M4 macrophages have yet to be shown. Macrophage-derived cytokines, chemokines, other factors, and possible effects are listed in the box. $\uparrow$, increase; $\downarrow$, decrease; $\rightarrow$, result or effect; $\mathrm{CO}$, carbon monoxide; $\mathrm{EC}$, endothelial cell; eNOS, endothelial nitric oxide synthase; HO-1, heme oxygenase-1; ICAM-1, intercellular adhesion molecule 1; MФ, macrophage; MMP, matrix metalloproteinase; SMC, smooth muscle cell; Srxn1, sulfiredoxin 1 homolog; Txnrd1, thioredoxin reductase 1; VCAM-1, vascular cell adhesion molecule 1.
In contrast to pro-inflammatory $\mathrm{M} 1, \mathrm{M} 2 \mathrm{M} \Phi$ s have been described as wound-healing $M \Phi$ s, based on their ability to promote wound healing through matrix remodeling, efferocytosis, and the recruitment of fibroblasts (Gordon and Martinez, 2010; Murray and Wynn, 2011). In general, M2 MФs characteristically express CD206, resistin-like molecule alpha (Relma; Fizz1), suppressor of cytokine signaling 2 (Socs2), interferon regulatory factor 4 (Irf4), chitinase, acidic (Chia), chitinase 3-like protein 2 (Chi311; Gp39, Ykl40), chitinase 3-like protein 2 (Chi3l2; Ykl39), chitinase 3-like protein 3 (Chi313; Ym1), CXCL13, CCL12, CCL24, and
Krüppel-like factor 4 (Klf4; Murray and Wynn, 2011), which can be used to identify them in vivo (Table 2). In the context of atherosclerosis, M2 M $\Phi$ s have been observed within both human and murine atheroma. Bouhlel et al. (2007) first demonstrated the presence of CD206 ${ }^{+} \mathrm{M} 2 \mathrm{M} \Phi$ s within human endarterectomy specimens in the stable areas of the plaque. Chinetti-Gbaguidi et al. (2011) demonstrated that $\mathrm{CD}^{+} 8^{+} \mathrm{CD} 206^{+} \mathrm{M} 2 \mathrm{M \Phi s}$, which localized far from the lipid core in comparison to $\mathrm{CD} 68^{+} \mathrm{CD} 206^{-}$ M1 MФs, contained smaller lipid droplets as demonstrated by Oil red $\mathrm{O}$ staining. 
Similar to M1 MФs, while the effects of M2-secreted cytokines, chemokines, and small molecules have not been specifically assessed in atherosclerosis, in vitro data and global cytokine knockout studies have provided some insight concerning the possible functions M2 MФs in vivo (Figure 1). Depending on the conditions in vitro, M2 M $\Phi$ s may produce anti-inflammatory cytokines including, IL-4, IL-13, IL-10. Based on studies of global cytokine knockout mice in atherosclerosis (Kleemann et al., 2008), M2 MФ-derived IL-4, IL-13, and IL-10, through their immunosuppressive effects on $\mathrm{T}$ cell and $\mathrm{M} \Phi$ activation, may lead to decreased endothelial cell and smooth muscle cell activation; leading to decreased pro-inflammatory chemokine expression, increased endothelial eNOS expression, vasorelaxation, and smooth muscle cell proliferation (Figure 1; Table 2). Additionally, M2-secreted IL-4, IL-13, and IL-10 may support the generation of anti-inflammatory Th2 cells and immunosuppressive Treg, favoring alternative inflammation. In contrast to M1

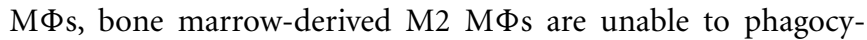
tose oxLDL efficiently but are highly effective efferocytes that secrete a variety of matrix metalloproteases (MMP2, MMP9, MMP12, MMP13, MMP14), suggesting that M2 MФs may promote the clearance of apoptotic cells in early atherosclerotic plaques but could destabilize the plaque in the advanced stages of the disease.

\section{Mox/Mha SUBSET OF MACROPHAGES}

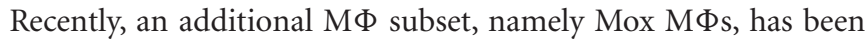
proposed (Kadl et al., 2010). Un-polarized bone marrow-derived $M \Phi$ cultures that were treated with the ox-PL 1-palmitoyl2arachidonoyl-sn-glycero-3-phosphorylcholine generated a population of $M \Phi$ s that expressed a unique profile of genes including Heme oxygenase-1 (HO-1), sufiredoxin-1 (Srnx1), and thioredoxin reductase 1 (Txnrd1) in a nuclear factor, erythroid-derived 2, like 2 (Nrf2) dependent manner (Kadl et al., 2010). This population of Mox MФs was also found within the aortas of 30 week western diet-fed $\mathrm{Ldlr}^{-/-}$mice by immunohistochemistry and flow cytometry. In addition to their hallmark expression of HO-1, Mox MФs expressed the anti-oxidant enzymes Txnrd1, and Srnx1 by immunofluorescence. This unique population of Mox $\left(\mathrm{CD} 45^{+} \mathrm{CD} 11 \mathrm{~b}^{+} \mathrm{F} 4 / 80^{+} \mathrm{HO}-1^{+}\right.$cells) M $\Phi$ s comprised $23 \%$ of the aortic $\mathrm{CD} 11 \mathrm{~b}^{+} \mathrm{F} 4 / 80^{+}$population. The remaining $39 \%$ of aortic $\mathrm{CD} 11 \mathrm{~b}^{+} \mathrm{F} 4 / 80^{+}$cells were classified as $\mathrm{CD} 11 \mathrm{~b}^{+} \mathrm{F} 4 / 80^{+} \mathrm{CD}^{+} 6^{+}$ M1 MФs and 22\% expressed the M2 marker CD206 (Kadl et al., 2010). The proposed phenotype of Mox M $\Phi$ s closely resembles the phenotype of the recently proposed hemorrhage-associated MФs (Mha; Boyle et al., 2009; Boyle et al., 2011). Human monocytederived $M \Phi$ s that are treated in vitro with hapto-hemoglobin complexes or oxidized red blood cells were found to upregulate CD163, HO-1, and IL-10 in an Nrf2-dependent manner (Boyle et al., 2009). These $\mathrm{CD} 163^{+} \mathrm{CD} 68^{+} \mathrm{M} \Phi$ s were associated with the fibrous cap region and regions of hemorrhage within human coronary artery plaques. These results suggest that Mox MФs, which are present within the atherosclerotic mouse lesions, are phenotypically similar to Mha MФs, and underscore the heterogeneity of $M \Phi$ s with atherosclerotic vessels.

At present, little is known about the functionality of Mox/Mha $\mathrm{M} \Phi$ s in vivo (Figure 1). As Mox/Mha MФs express IL-10, VEGF, and enzymes with anti-oxidizing activities, they may exert antiinflammatory actions on the vasculature in vivo. In this regard, HO-1, Srxn1, and Txnrd1, through the sequestration of iron, the production of bilirubin, and carbon monoxide (Otterbein et al., 2003; Wolfs et al., 2011), may protect endothelial cells and smooth muscle cells from oxidative stress and promote vasorelaxation through the production of carbon monoxide (Figure 1; Table 2). In addition, Mox/Mha-derived IL-10 and VEGF may play antiinflammatory roles through the suppression of T-cell and M $\Phi$ activation, and the promotion of endothelial cell proliferation and survival, respectively (Kadl et al., 2010; Wolfs et al., 2011). However, data from in vitro phagocytosis assays demonstrated that Mox $M \Phi$ s are poor efferocytes and are only weakly able to phagocytose oxLDL, suggesting that Mox/Mha MФs may not be able to effectively clear apoptotic cells and resolve inflammation in vivo (Kadl et al., 2010; Wolfs et al., 2011).

\section{M4 MACROPHAGES}

Recently, Gleissner et al. (2010b) identified a unique subset of MCSF/CXCL4-dependent macrophages that was termed M4 MФs. M4 MФs expressed a unique set of transcripts, including higher levels of $C d 86$, tumor necrosis factor (ligand) superfamily member 10 (Tnfsf10), mannose receptor, c type 1 (Mrc1), Ccl18, Ccl22, Tnf, and lower levels of pentraxin 3 (Ptx3), Cd36, and Il10. In this study, M4 MФs were weakly phagocytic and unable to efficiently phagocytize acLDL or oxLDL, suggesting that M4 MФs may not readily become foam cells or function as efferocytes within atherosclerotic plaques. The functions of M4 MФs remains poor understood. In the context of atherosclerosis, atherosclerotic lesions have been demonstrated to contain M1, M2, and M4 marker-expressing $M \Phi s$, suggesting that the pool of lesional $M \Phi$ s may play different roles in the pathology of atherosclerosis (Figure 1; Table 2). For more information on $\mathrm{M} 4 \mathrm{M} \Phi$ s we refer the reader to the pertinent review by $\mathrm{C}$. Gleissner in this issue.

\section{MIXED PHENOTYPE AND PLASTICITY OF MACROPHAGE SUBSETS}

Although the in vitro conditions of generation of $M \Phi$ subsets are very distinct and require specific sets of cytokines, several

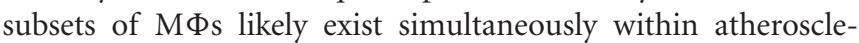
rotic aortas in vivo. As alluded to in the preceding sections, the murine and human atherosclerotic plaque $M \Phi$ pool is, in reality, comprised of a complex mixture of $M \Phi$ subsets; which work together to result in the progression and persistence of atherosclerotic plaques. There is some evidence, mainly from in vitro studies, to suggest that the phenotypes of $M \Phi$ subsets are not fixed, and that these cells possess some phenotypic plasticity in response to micro-environmental factors. For example, KhallouLaschet et al. (2010) reported that bone marrow-derived MФs from C57BL/ 6 and Apoe $e^{-/-}$mice driven to M1 or M2 phenotypes are able to assume the opposing phenotype (M2 or M1, respectively) when the culture conditions are switched. This idea is also supported by the work of Feig et al. (2011), in which murine aortic sections were examined for the expression of M2 MФ markers in a model of athero-regression via laser capture microdissection. Apoe $e^{-/-}$aortic arches were transplanted into C57BL/6, $A p o A I^{-/-}$, human apoAI Apoe $e^{-/-}$transgenic, and Apoe ${ }^{-/-}$mice 
and assessed for pro-inflammatory chemokines, MHC, class 1related (Mr1), Cd163, C-lectin, and Fizz-1 expression 1-week post transplantation. In this model, lesional $\mathrm{CD}^{+} 8^{+} \mathrm{M} \Phi$ s expressed higher levels of M2 markers within athero-regressive C57BL/6 and hApoeAI Apoe $e^{-/-}$transgenic mice, suggesting that plaque M $\Phi$ s can assume a M2 phenotype in the athero-regressive state. Recently in different system, Liao et al. (2011) examined the role of Krüppel-like factor 4 (KLF-4) in $M \Phi$ polarization in vitro, and in a model of diet-induced obesity. KLF4 was strongly induced in M2 MФs, where it interacted with Stat-6 to reinforce the expression of M2 genes and antagonized M1 gene expression via the sequestration of co-activators of $\mathrm{NF}-\mathrm{kB}$ activation in vitro. In a model of diet-induced obesity, LysM-Cre-Klff $4^{\text {flox/flox }} \mathrm{C} 57 \mathrm{BL} / 6$ bone marrow chimeras displayed significant increases in total body weight, subcutaneous and visceral fat depot sizes, glucose intolerance, and insulin resistance, which corresponded with elevated M1 related gene expression within the stromal vascular fractions of LysM-CreKlf4 $4^{\text {flox/flox }}$ C57BL/6 chimeras in comparison to Klf4 ${ }^{\text {flox/flox }} \mathrm{C} 57 \mathrm{BL} / 6$ chimeras. These results suggest that KLF4 may similarly play a role in the formation of M2 MФs in atherosclerotic plaques.

Thus, at present, the functions and specific contributions of $M \Phi$ subsets to the pathogenesis of atherosclerosis are largely unknown. While in vitro $\mathrm{M} \Phi$ polarization and global cytokine knockout studies have provided some mechanistic insight, novel techniques to specifically target $М \Phi$ subsets or $M \Phi$ effector molecules are necessary to further clarify the roles of $M \Phi$ subsets in atherosclerosis. In addition, anticipated follow-up studies of Mox/Mha and M4 MФ in atherosclerosis should help to clarify the functions of these subsets in atherogenesis.

To date, it is clear that both MФs and DCs display phenotypic and functional heterogeneity within atherosclerotic and non-diseased arteries. However, as the majority of the studies have examined either DC or macrophage heterogeneity at a single time point, it is unclear how these two populations change as atherosclerotic plaques develop and progress. According to the American Heart Association guidelines for the histological classification of atherosclerotic plaques, there are six distinct stages of atherosclerotic lesions (Stary et al., 1995). These stages range from clinically silent initial (I), fatty streak (II), and intermediate lesions (III), to clinically overt atheroma (IV), fibroatheroma (V), and complicated lesions (VI). Mouse models of atherosclerosis, including $A p o e^{-/-}$and $\mathrm{Ldlr}^{-/-}$mice, develop atherosclerotic lesions in a similar manner, ranging from initial (I), fatty streak (II) lesions to intermediate (III), atheroma (IV), and fibrous plaques (V) (Nakashima et al., 1994). Thus, based on these lesion stage definitions, we have noted (Table 1) the stage(s) at which dendritic and macrophage subsets have been observed. In general, while mouse studies have primarily focused on DCs in the non-atherosclerotic C57BL/6 aorta or initial stages of atherosclerosis in $A p o e^{-/-}$and $\mathrm{Ldlr}^{-/-}$mice, human studies have focused on vascular DCs within late stage symptomatic or asymptomatic endarterectomy patients. As DC subsets have been shown to exert pro-inflammatory (Weber et al., 2011) and tolerogenic (Choi et al., 2011) functions, examining the dynamics of DC subset recruitment and functions within the aorta during atherogenesis will likely result in new therapeutic opportunities for targeting pro-inflammatory DCs or developing vaccines. Similarly, while $M \Phi$ s represent the majority of leukocytes within atherosclerotic plaques, the specific functions of $M \Phi$ subsets have only recently come under consideration. While macrophages are present throughout the development of atherosclerosis, little is known about the specific recruitment or egress of $\mathrm{M} 1$ and $\mathrm{M} 2 \mathrm{M} \Phi$ s from atherosclerotic plaques.

\section{CONCLUDING REMARKS}

Our understanding of the mechanisms of atherosclerosis has notably progressed in parallel with work adding to our understanding of immune system under homeostatic and inflammatory conditions. Recent breakthrough discoveries on the plasticity and heterogeneity of monocytes, MФs, and DCs have opened new directions for the investigation and further understanding of the potential roles of multiple subsets of DCs and MФs in the initiation, maintenance and resolution of atherosclerosis. To date, multiple lines of evidence clearly demonstrate that DCs and MФs represent heterogeneous populations with distinct phenotypes in vitro and in vivo within atherosclerotic aortas. However, the functions and specific mechanisms that control the generation of distinct $M \Phi$ and DC subsets within atherosclerotic vessels are poorly understood. In this review, we have focused on the characterization and potential implications of DC and $M \Phi$ subsets within healthy and atherosclerotic aortas (Tables 1 and 2).

Our current understanding of the functions of $M \Phi$ subsets in vivo relies heavily upon their generation and functions in vitro, as well as, the effects of global cytokine, chemokine, and enzyme knockouts, rather than the effects of $M \Phi$ subset-specific knockouts. Cell-type specific knockouts using the Cre-Lox recombination strategy and transgenic mice have been used to specifically knockout genes within myeloid cells; however, as the expression profiles of different myeloid cells can be fairly similar, unintended effects can occur. Unfortunately, at present, $M \Phi$ subset-specific Cre-mice have not been reported, and the precise functions of $M \Phi$ subsets in vivo remain somewhat elusive.

What may we conclude at the present time about the effects of different subsets of DCs and MФs on the biology of the aorta? First, distinct subsets of resident aortic DC and MФs may be important contributors to balancing the activation and suppressor arms of the immune response within the normal, non-inflamed aorta. Additional studies that will be devoted to the biology of healthy aortas should clarify the consequences of early events during the induction of atherosclerosis, and identify unique roles for each subset of DC and $M \Phi$ for each step of atherosclerosis. As atherosclerosis is an age- and time-related disease, the kinetics of induction and the molecular and cellular events that underlie these events are important and may provide novel therapeutic opportunities. Second, several intriguing studies have suggested that $\mathrm{M} \Phi$ s and DCs are comprised of a diverse group of cells in atherosclerosis. DC subsets are found within healthy and atherosclerosis-prone aortas and understanding how different subsets of DCs respond to lipid uptake will help to advance the field. It is unclear if all DCs serve as antigen-presenting cells, and very little is currently known about a preferential subset of DCs that is responsible for T cell-induced inflammation within the aorta. Similarly, several subsets of MФs 
are present within healthy and atherosclerotic arteries. While M1 $\mathrm{M} \Phi$ s likely play a critical role in the pathology of atherosclerosis, the relationship between $M 1 M \Phi s$ and other $M \Phi$ subsets, as well as the possibility of phenotypic plasticity within atherosclerotic plaques are unknown. Third, it would be important to identify the pathway(s) through which $\mathrm{CD} 11 \mathrm{c}^{+}$cells may modulate the levels of plasma cholesterol. Additionally, while we have considerable knowledge about the recruitment of monocyte subsets to and exit from the atherosclerotic plaques, it is still uncertain whether the efflux or retention of DCs is regulated by the plasma

\section{REFERENCES}

Angeli, V., Llodra, J., Rong, J. X., Satoh, K., Ishii, S., Shimizu, T., Fisher, E. A., and Randolph, G. J. (2004). Dyslipidemia associated with atherosclerotic disease systemically alters dendritic cell mobilization. Immunity 21, 561-574.

Anitschkow, N. (1913). Uber die veranderungen der kaninchenaorta bei experimenteller cholesterinsteatose. Beitr. Pathol. Anat. 56, 379-404.

Annacker, O., Coombes, J. L., Malmstrom, V., Uhlig, H. H., Bourne, T., Johansson-Lindbom, B., Agace, W. W., Parker, C. M., and Powrie, F. (2005) Essential role for CD103 in the $\mathrm{T}$ cell-mediated regulation of experimental colitis. J. Exp. Med. 202, 1051-1061.

Blanden, R. V., Lefford, M. J., and Mackaness, G. B. (1969). The host response to Calmette-Guerin bacillus infection in mice. J. Exp. Med. 129, 1079-1107.

Bluml, S., Kirchberger, S., Bochkov, V. N., Kronke, G., Stuhlmeier, K., Majdic, O., Zlabinger, G. J., Knapp, W., Binder, B. R., Stockl, J., and Leitinger, N. (2005). Oxidized phospholipids negatively regulate dendritic cell maturation induced by TLRs and CD40. J. Immunol. 175, 501-508.

Bobryshev, Y. V. (2010). Dendritic cells and their role in atherogenesis. Lab. Invest. 90, 970-984.

Bobryshev, Y. V., and Lord, R. S. (1995). Ultrastructural recognition of cells with dendritic cell morphology in human aortic intima. Contacting interactions of vascular dendritic cells in athero-resistant and atheroprone areas of the normal aorta. Arch. Histol. Cytol. 58, 307-322.

Bobryshev, Y. V., and Lord, R. S. (1998). Mapping of vascular dendritic cells in atherosclerotic arteries suggests their involvement in local immuneinflammatory reactions. Cardiovasc. Res. 37, 799-810.

Bobryshev, Y. V., Moisenovich, M. M., Pustovalova, O. L., Agapov, I. I., and Orekhov, A. N. (2011). Widespread distribution of HLA-DR-expressing cells in macroscopically undiseased intima of the human aorta: A possible role in surveillance and maintenance of vascular homeostasis. Immunobiology 22.

Bouhlel, M. A., Derudas, B., Rigamonti, E., DiFvart, R., Brozek, J., Haulon, S., Zawadzki, C., Jude, B., Torpier, G., Marx, N., Staels, B., and Chinetti-Gbaguidi, G. (2007). PPAR[gamma] Activation Primes Human Monocytes into Alternative M2 Macrophages with Anti-inflammatory Properties. Cell Metab. 6, 137-143.

Boyle, J. J., Harrington, H. A., Piper, E., Elderfield, K., Stark, J., Landis, R. C., and Haskard, D. O. (2009). Coronary intraplaque hemorrhage evokes a novel atheroprotective macrophage phenotype. Am. J. Pathol. 174, 1097-1108.

Boyle, J. J., Johns, M., Lo, J., Chiodini, A., Ambrose, N., Evans, P. C., Mason, J. C., and Haskard, D. O. (2011). Heme induces heme oxygenase 1 via $\mathrm{Nrf2}$ : role in the homeostatic macrophage response to intraplaque hemorrhage. Arterioscler. Thromb. Vasc. Biol. 31, 2685-2691.

Butcher, M., and Galkina, E. (2011). Current views on the functions of interleukin-17A-producing cells in atherosclerosis. Thromb. Haemost. 106, 787-795.

Cheong, C., Matos, I., Choi, J. H., Dandamudi, D. B., Shrestha, E., Longhi, M. P., Jeffrey, K. L., Anthony, R. M., Kluger, C., Nchinda, G., Koh, H., Velinzon, K., Park, C. G., and Steinman R. M. (2010). Microbial stimulation fully differentiates monocytes to DC-SIGN/CD209(+) dendritic cells for immune $\mathrm{T}$ cell areas. Cell 143, 16-29.

Chinetti-Gbaguidi, G., Baron, M., Bouhlel, M. A., Vanhoutte, J., Copin, C., Sebti, Y., Derudas, B., Mayi, T., Bories, G., Tailleux, A., Haulon, S., Zawadzki, C., Jude, B., and Staels, B. (2011). Human atherosclerotic plaque alternative macrophages display low cholesterol handling but Rodriguez, A., Idoyaga, J., Pack, M.

cholesterol levels. Finally, DC-based vaccination provides some promising data for the treatment of atherosclerosis, but several questions such as specificity of antigens, choice of adjuvants and optimal type of DCs used for vaccination remain to be better investigated.

\section{ACKNOWLEDGMENTS}

This work was supported by American Heart Association Predoctoral Fellowship grant 11PRE7520041 (to Matthew Butcher) and by the NHLBI HL107522 (to Elena Galkina).

high phagocytosis because of distinct activities of the PPARgamma and LXRalpha pathways. Circ. Res. 108, 985-995.

Choi, J. H., Cheong, C., Dandamudi, D. B., Park, C. G., Rodriguez, A., Mehandru, S., Velinzon, K., Jung, I. H., Yoo, J. Y., Oh, G. T., and Steinman, R. M. (2011). Flt3 signalingdependent dendritic cells protect against atherosclerosis. Immunity 35, 819-831.

Choi, J. H., Do, Y., Cheong, C., Koh, H., Boscardin, S. B., Oh, Y. S., Bozzacco, L., Trumpfheller, C., Park, C. G., and Steinman, R. M. (2009). Identification of antigen-presenting dendritic cells in mouse aorta and cardiac valves. J. Exp. Med. 206, 497-505.

Colonna, M., Trinchieri, G., and Liu, Y. J. (2004). Plasmacytoid dendritic cells in immunity. Nat. Immunol. 5, 1219-1226.

Daissormont, I. T., Christ, A., Temmerman, L., Sampedro, M. S., Seijkens, T., Rousch, M., Poggi, M., Boon, L., van der Loos, C., Daemen, M., Lutgens, E., Halvorsen, B., Aukrust, P., Janssen, E., and Biessen, E. A. (2011). Plasmacytoid dendritic cells protect against atherosclerosis by tuning $\mathrm{T}$ cell proliferation and activity. Circ. Res.109, 1387-1395.

de Jager, S. C., and Kuiper, J. (2011) Vaccination strategies in atherosclerosis. Thromb. Haemost. 106, 796-803.

Erbel, C., Sato, K., Meyer, F. B., Kopecky, S. L., Frye, R. L., Goronzy, J. J., and Weyand, C. M. (2007). Functional profile of activated dendritic cells in unstable atherosclerotic plaque. Basic Res. Cardiol. 102, 123-132.

Feig, J. E., Rong, J. X., Shamir, R., Sanson, M., Vengrenyuk, Y., Liu, J., Rayner, K., Moore, K., Garabedian, M., and Fisher, E. A. (2011). HDL promotes rapid atherosclerosis regression in mice and alters inflammatory properties of plaque monocyte-derived cells. Proc. Natl. Acad. Sci. U.S.A. 108 7166-7171.

Galkina, E., Kadl, A., Sanders, J., Varughese, D., Sarembock, I. J., and Ley,
K. (2006). Lymphocyte recruitment into the aortic wall before and during development of atherosclerosis is partially L-selectin dependent. J. Exp. Med. 203, 1273-1282.

Galkina, E., and Ley, K. (2009). Immune and inflammatory mechanisms of atherosclerosis (*). Annu. Rev. Immunol. 27, 165-197.

Gautier, E. L., Huby, T., Saint-Charles, F., Ouzilleau, B., Pirault, J., Deswaerte, V., Ginhoux, F., Miller, E. R., Witztum, J. L., Chapman, M. J., and Lesnik, P. (2009). Conventional dendritic cells at the crossroads between immunity and cholesterol homeostasis in atherosclerosis. Circulation 119, 2367-2375.

Geissmann, F., Gordon, S., Hume, D. A., Mowat, A. M., and Randolph, G. J. (2010). Unravelling mononuclear phagocyte heterogeneity. Nat. Rev. Immunol. 10, 453-460.

Gerrity, R. G. (1981). The role of the monocyte in atherogenesis: I. Transition of blood-borne monocytes into foam cells in fatty lesions. Am. J. Pathol. 103, 181-190.

Gleissner, C. A., Shaked, I., Erbel, C., Böckle,r D., Katus, H. A., and Ley, K. (2010a). CXCL4 downregulates the atheroprotective hemoglobin receptor CD163 in human macrophages. Circ. Res. 106, 203-211.

Gleissner, C. A., Shaked, I., Little, K. M., and Ley, K. (2010b). CXC chemokine ligand 4 induces a unique transcriptome in monocytederived macrophages. J. Immunol. 184, 4810-4818.

Gordon, S., and Martinez, F. O. (2010). Alternative activation of macrophages: mechanism and functions. Immunity 32, 593-604.

Gordon, S., and Taylor, P. R. (2005). Monocyte and macrophage heterogeneity. Nat. Rev. Immunol. 5, 953-964.

Han, J. W., Shimada, K., Ma-Krupa, W., Johnson, T. L., Nerem, R. M., Goronzy, J. J., and Weyand, C. M. (2008). Vessel wall-embedded dendritic cells induce T-cell autoreactivity and initiate vascular inflammation. Circ. Res. 102, 546-553. 
Hansson, G. K., Bondjers, G., Bylock, A., and Hjalmarsson, L. (1980). Ultrastructural studies on the localization of IgG in the aortic endothelium and subendothelial intima of atherosclerotic and nonatherosclerotic rabbits. Exp. Mol. Pathol. 33, 302-315.

Hermansson, A., Ketelhuth, D. F., Strodthoff, D., Wurm, M., Hansson, E. M., Nicoletti, A., PaulssonBerne, G., and Hansson, G. K. (2010). Inhibition of $\mathrm{T}$ cell response to native low-density lipoprotein reduces atherosclerosis. J. Exp. Med. 207, 1081-1093.

Hoff, H. H. (1972). Human intracranial atherosclerosis. A histochemical and ultrastructural study of gross fatty steak lesions. Am. J. Pathol. 69, 421-438.

Jonasson, L., Holm, J., Skalli, O., Bondjers, G., and Hansson, G. K. (1986). Regional accumulations of $\mathrm{T}$ cells, macrophages, and smooth muscle cells in the human atherosclerotic plaque. Arteriosclerosis 6, 131-138.

Jongstra-Bilen, J., Haidari, M., Zhu, S. N., Chen, M., Guha, D., and Cybulsky, M. I. (2006). Low-grade chronic inflammation in regions of the normal mouse arterial intima predisposed to atherosclerosis. J. Exp. Med. 203, 2073-2083.

Joris, I., Stetz, E., and Majno, G. (1979). Lymphocytes and monocytes in the aortic intima-An electron-microscopic study in the rat. Atherosclerosis 34, 221-231.

Kadl, A., Meher, A. K., Sharma, P. R., Lee, M. Y., Doran, A. C., Johnstone, S. R., Elliott, M. R., Gruber, F., Han, J., Chen,W., Kensler, T., Ravichandran, K. S., Isakson, B. E., Wamhoff, B. R., and Leitinger, N. (2010). Identification of a novel macrophage phenotype that develops in response to atherogenic phospholipids via Nrf2. Circ. Res. 107, 737-746.

Khallou-Laschet, J., Varthaman, A., Fornasa, G., Compain, C., Gaston, A. T., Clement, M., Dussiot, M., Levillain, O., Graff-Dubois, S., Nicoletti, A., and Caligiuri, G. (2010). Macrophage plasticity in experimental atherosclerosis. PLOS ONE 5, e8852.

Kleemann, R., Zadelaar, S., and Kooistra, T. (2008). Cytokines and atherosclerosis: a comprehensive review of studies in mice. Cardiovasc. Res. 79, 360-376.

Ley, K., Miller, Y. I., and Hedrick, C. C. (2011). Monocyte and macrophage dynamics during atherogenesis. Arterioscler. Thromb. Vasc. Biol. 31, 1506-1516.

Lewkowich I. P., Lajoie S., Clark J. R., Herman N. S., Sproles A. A., and Wills-Karp M. (2008). Allergen uptake, activation, and IL-23 production by pulmonary myeloid DCs drives airway hyperresponsiveness in asthma-susceptible mice. PLoS ONE 3, e3879.

Liao, X., Sharma, N., Kapadia, F., Zhou, G., Lu, Y., Hong, H., Paruchuri, K., Mahabeleshwar, G. H., Dalmas, E., Venteclef, N., Flask, C. A., Kim, J., Doreian, B. W., Lu, K. Q., Kaestner, K. H., Hamik, A., Clement, K., and Jain, M. K. (2011). Kruppel-like factor 4 regulates macrophage polarization. J. Clin. Invest. 121, 2736-2749.

Liu, K., Victora, G. D., Schwickert, T. A., Guermonprez, P., Meredith, M. M., Yao, K., Chu, F. F., Randolph, G. J., Rudensky, A. Y., and Nussenzweig, M. (2009). In vivo analysis of dendritic cell development and homeostasis. Science 324, 392-397.

Llodra, J., Angeli, V., Liu, J., Trogan, E., Fisher, E. A., and Randolph, G. J. (2004). Emigration of monocytederived cells from atherosclerotic lesions characterizes regressive, but not progressive, plaques. Proc. Natl. Acad. Sci. U.S.A. 101, 11779-11784.

Ma-Krupa, W., Jeon, M. S., Spoerl, S., Tedder, T. F., Goronzy, J. J., and Weyand, C. M. (2004). Activation of arterial wall dendritic cells and breakdown of self-tolerance in giant cell arteritis. J. Exp. Med. 199, 173-183.

Manthey, H. D., and Zernecke, A. (2011). Dendritic cells in atherosclerosis: functions in immune regulation and beyond. Thromb. Haemost. 106, 772-778.

Martinez, F. O., Gordon, S., Locati, M., and Mantovani, A. (2006). Transcriptional profiling of the human monocyte-to-macrophage differentiation and polarization: new molecules and patterns of gene expression. J. Immunol. 177, 7303-7311.

Matsuura, E., Kobayashi, K., Tabuchi, M., and Lopez, L. R. (2006). Oxidative modification of low-density lipoprotein and immune regulation of atherosclerosis. Prog. Lipid Res. 45, 466-486.

Matta, B. M., Castellaneta, A., and Thomson, A. W. (2010). Tolerogenic plasmacytoid DC. Eur. J. Immunol. 40, 2667-2676.

Millonig, G., Niederegger, H., Rabl, W., Hochleitner, B. W., Hoefer, D., Romani, N., and Wick, G. (2001). Network of vascular-associated dendritic cells in intima of healthy young individuals. Arterioscler. Thromb. Vasc. Biol. 21, 503-508.

Moore, K. J., and Tabas, I. (2011). Macrophages in the pathogenesis of atherosclerosis. Cell 145, 341-355.
Mosser, D. M., and Edwards, J. P. (2008). Exploring the full spectrum of macrophage activation. Nat. Rev. Immunol. 8, 958-969.

Murray, P. J., and Wynn, T. A. (2011). Protective and pathogenic functions of macrophage subsets. Nat. Rev. Immunol. 11, 723-737.

Naik, S. H., Metcalf, D., van Nieuwenhuijze, A., Wicks, I., Wu, L., O’Keeffe, M., and Shortman K. (2006). Intrasplenic steady-state dendritic cell precursors that are distinct from monocytes. Nat. Immunol. 7 , 663-671.

Nakajima, K., Yamashita, T., Kita, T., Takeda, M., Sasaki, N., Kasahara, K., Shinohara, M., Rikitake, Y., Ishida, T., Yokoyama, M., and Hirata, K. (2011). Orally administered eicosapentaenoic acid induces rapid regression of atherosclerosis via modulating the phenotype of dendritic cells in LDL receptordeficient mice. Arterioscler. Thromb. Vasc. Biol. 31, 1963-1972.

Nakashima Y., Plump A. S., Raines E. W., Breslow J. L., and Ross R. (1994). ApoE-deficient mice develop lesions of all phases of atherosclerosis throughout the arterial tree. Arterioscler. Thromb. 14 133-140.

Niessner, A., Sato, K., Chaikof, E. L., Colmegna, I., Goronzy, J. J., and Weyand, C. M. (2006). Pathogensensing plasmacytoid dendritic cells stimulate cytotoxic T-cell function in the atherosclerotic plaque through interferon-alpha. Circulation 114, 2482-2489.

Niessner, A., and Weyand, C. M. (2010). Dendritic cells in atherosclerotic disease. Clin. Immunol. 134, 25-32.

Onai, N., Obata-Onai, A., Tussiwand, R., Lanzavecchia, A., and Manz MG. (2006) Activation of the Flt3 signal transduction cascade rescues and enhances type I interferon-producing and dendritic cell development. J. Exp. Med. 203, 227-238.

Otterbein, L. E., Soares, M. P., Yamashita, K., and Bach, F. H. (2003). Heme oxygenase-1: unleashing the protective properties of heme. Trends Immunol. 24, 449-455.

Packard, R. R., Maganto-Garcia, E. Gotsman, I., Tabas, I., Libby, P., and Lichtman, A. H. (2008). CD11c(+) dendritic cells maintain antigen processing, presentation capabilities, and CD4(+) T-cell priming efficacy under hypercholesterolemic conditions associated with atherosclerosis. Circ. Res. 103, 965-973.

Paulson, K. E., Zhu, S. N., Chen, M., Nurmohamed, S., Jongstra-Bilen, J., and Cybulsky, M. I. (2010). Resident intimal dendritic cells accumulate lipid and contribute to the initiation of atherosclerosis. Circ. Res. 106, 383-390.

Perrin-Cocon, L., Coutant, F., Agaugue, S., Deforges, S., Andre, P., and Lotteau, V. (2001). Oxidized low-density lipoprotein promotes mature dendritic cell transition from differentiating monocyte. J. Immunol. 167, 3785-3791.

Pulendran B., Smith J. L., Caspary G., Brasel K., Pettit D., Maraskovsky E. and Maliszewski C. R. (1999). Distinct dendritic cell subsets differentially regulate the class of immune response in vivo. Proc. Natl. Acad. Sci. U.S.A. 96, 1036-1041.

Randolph, G. J. (2009). The fate of monocytes in atherosclerosis. $J$. Thromb. Haemost. 7, 28-30.

Reizis, B., Bunin, A., Ghosh, H. S., Lewis, K. L., and Sisirak, V. (2011). Plasmacytoid dendritic cells: recent progress and open questions. Annu. Rev. Immunol. 29, 163-183.

Sato, K., Niessner, A., Kopecky, S. L., Frye, R. L., Goronzy, J. J., and Weyand, C. M. (2006). TRAILexpressing $\mathrm{T}$ cells induce apoptosis of vascular smooth muscle cells in the atherosclerotic plaque. J. Exp. Med. 203, 239-250.

Smith, J. D., Trogan, E., Ginsberg, M., Grigaux, C., Tian, J., and Miyata, M. (1995). Decreased atherosclerosis in mice deficient in both macrophage colony-stimulating factor (op) and apolipoprotein E. Proc. Natl. Acad. Sci. U.S.A. 92, 8264-8268.

Stanley, E. R., Chen, D. M., and Lin, H. S. (1978). Induction of macrophage production and proliferation by a purified colony stimulating factor. Nature 274, 168-170.

Stary H. C., Chandler A. B., Dinsmore R. E., Fuster V., Glagov S., Insull W., Rosenfeld M. E., Schwartz C. J., Wagner W. D., and Wissler R. W. (1995). A definition of advanced types of atherosclerotic lesions and a histological classification of atherosclerosis. A report from the Committee on Vascular Lesions of the Council on Arteriosclerosis, American Heart Association. Arterioscler. Thromb. Vasc. Biol. 15, 1512-1531.

Stein, M., Keshav, S., Harris, N., and Gordon, S. (1992). Interleukin 4 potently enhances murine macrophage mannose receptor activity: a marker of alternative immunologic macrophage activation. J. Exp. Med. 176, 287-292. 
Steinman, R. M. (2007). Dendritic cells: understanding immunogenicity. Eur. J. Immunol. 37, S53-S60.

Steinman, R. M., Hawiger, D., and Nussenzweig, M. C. (2003). Tolerogenic dendritic cells. Annu. Rev. Immunol. 21, 685-711.

Stoneman, V., Braganza, D., Figg, N., Mercer, J., Lang, R., Goddard, M., and Bennett, M. (2007). Monocyte/macrophage suppression in CD11b diphtheria toxin receptor transgenic mice differentially affects atherogenesis and established plaques. Circ. Res. 100, 884-893.

Swirski, F. K., Weissleder, R., and Pittet, M. J. (2009). Heterogeneous in vivo behavior of monocyte subsets in atherosclerosis. Arterioscler. Thromb. Vasc. Biol. 29, 1424-1432.

Tabas, I. (2010). Macrophage death and defective inflammation resolution in atherosclerosis. Nat. Rev. Immunol. $10,36-46$.
Villadangos, J. A., and Young, L. (2008). Antigen-presentation properties of plasmacytoid dendritic cells. Immunity 29, 352-361.

Waltner-Romen, M., Falkensammer, G., Rabl, W., and Wick, G. (1998). A previously unrecognized site of local accumulation of mononuclear cells. The vascular-associated lymphoid tissue. J. Histochem. Cytochem. 46, 1347-1350.

Weber, C., Meiler, S., Doring, Y., Koch, M., Drechsler, M., Megens, R. T., Rowinska, Z., Bidzhekov, K., Fecher, C., Ribechini, E., van Zandvoort, M. A., Binder, C. J., Jelinek, I., Hristov, M., Boon, L., Jung, S., Korn, T., Lutz, M. B., Forster, I., Zenke, M., Hieronymus, T., Junt, T., and Zernecke, A. (2011). CCL17-expressing dendritic cells drive atherosclerosis by restraining regulatory $\mathrm{T}$ cell homeostasis in mice. J. Clin. Invest. 121, 2898-2910.
Wolfs, I. M., Donners, M. M., and de Winther, M. P. (2011). Differentiation factors and cytokines in the atherosclerotic plaque micro-environment as a trigger for macrophage polarisation. Thromb. Haemost. 106, 763-771.

Wu, H., Gower, R. M., Wang, H., Perrard, X. Y., Ma, R., Bullard, D. C., Burns, A. R., Paul, A., Smith, C. W., Simon, S. I., and Ballantyne, C. M. (2009). Functional role of CD11c+ monocytes in atherogenesis associated with hypercholesterolemia. Circulation 119, 2708-2717.

Zhu, S. N., Chen, M., Jongstra-Bilen, J., and Cybulsky, M. I. (2009). GM-CSF regulates intimal cell proliferation in nascent atherosclerotic lesions. J. Exp. Med. 206, 2141-2149.

Conflict of Interest Statement: The authors declare that the research was conducted in the absence of any commercial or financial relationships that could be construed as a potential conflict of interest.

Received: 20 December 2011; paper pending published: 12 January 2012; accepted 20 February 2012; published online: 19 March 2012

Citation: Butcher MJ and Galkina EV (2012) Phenotypic and functional heterogeneity of macrophages and dendritic cell subsets in the healthy and atherosclerosisprone aorta. Front. Physio. 3:44. doi: 10.3389/fphys.2012.00044

This article was submitted to Frontiers in Vascular Physiology, a specialty of Frontiers in Physiology.

Copyright () 2012 Butcher and Galkina. This is an open-access article distributed under the terms of the Creative Commons Attribution Non Commercial License, which permits non-commercial use, distribution, and reproduction in other forums, provided the original authors and source are credited. 